\title{
INTERRELIGIOUS TOLERANCE IN THE PERCEPTION OF MALUKU MUSLIM SOCIETY
}

\author{
Muhammad Amri \\ Universitas Islam Negeri Alauddin Makassar \\ muhammad.amri@uin-alauddin.ac.id \\ Musafir \\ Universitas Islam Negeri Alauddin Makassar \\ Musafirs3@gmail.com \\ Risna Mosiba \\ Universitas Islam Negeri Alauddin Makassar \\ rhiesnamos@gmail.com \\ Saidna Zulfiqar Bin-Tahir \\ University of Iqra Buru, Maluku \\ saidnazulfiqar@gmail.com
}

\begin{abstract}
All religions teach peace and welfare to their adherents through tolerance. The religious teaching, however, can also be the trigger of interreligious conflicts as it happened in Ambon in 1999-2011. This study aimed at determining whether or not the knowledge, education level, perception, and attitudes of the Ambones' Muslim community affect the interreligious tolerance in Ambon. This research employed quantitative research using survey design. The sample of the study consisted of 100 Muslims in Ambon city. The data have been collected through a questionnaire distributed, and they have been analyzed descriptively and inferentially using the SPSS program. The results found that the knowledge, level of education, perception, and attitude of the Ambones' Muslim community collectively had a positive impact on the interreligious tolerance amongst the Ambones' community. However, this perception has no significant effect on tolerance partially. The results of this study contributed to prevent and manage further unpredictable of interreligious conflict in the city of Ambon, Maluku.
\end{abstract}

Keywords: Muslims Maluku, perception, attitude, interreligious tolerance

\begin{abstract}
Abstrak
Semua agama mengajarkan perdamaian dan kesejahteraan bagi penganutnya melalui toleransi. Namun, ajaran agama juga bisa menjadi pemicu konflik antaragama seperti yang terjadi di Ambon pada 1999-2011. Studi ini bertujuan untuk menentukan apakah
\end{abstract}


pengetahuan, tingkat pendidikan, persepsi, dan sikap komunitas Muslim Ambon mempengaruhi toleransi antaragama di Maluku. Penelitian ini menggunakan penelitian kuantitatif dengan menggunakan desain survei. Sampel penelitian terdiri dari 100 Muslim di kota Ambon. Data dikumpulkan melalui kuesioner dan dianalisis secara deskriptif dan inferensial menggunakan program SPSS 19. Hasil penelitian menemukan bahwa pengetahuan, tingkat pendidikan, persepsi, dan sikap komunitas Muslim Ambon secara kolektif memiliki dampak positif pada toleransi antaragama di antara masyarakat Ambon. Namun, persepsi ini tidak berpengaruh signifikan terhadap toleransi secara parsial. Hasil dari penelitian ini berkontribusi untuk mencegah dan mengelola konflik antaragama yang tidak dapat diprediksi lebih lanjut di kota Ambon, Maluku.

Kata kunci: persepsi, muslim Maluku, sikap, toleransi antar agama

\section{A. Introduction}

Diversity is a specific thing from life on this earth. There are so many differences and variety that we often find around us. Especially for those who live in Indonesia, a country that has the motto "Unity in Diversity; Different but still one." From this motto, we know that the Indonesian State has a great deal of diversity. It is this diversity that makes Indonesian people called a plural society.

Indonesia, based on the 2018 population census, has a population of 267.7 million, making this country the 4 th most populous country in the world. This number is expected to continue to grow so that it is projected that in 2019 Indonesia's population will be 268 million and 305 million in $2035^{1}$.

The diversity of the population is certainly due to the religion, ethnicity, race, ethnicity, language, and culture. From that diversity, which sometimes leads to conflicts caused by differences in group ideology? Intolerance and discrimination also often occur, primarily related to religion. Given that Indonesia has a great diversity of religions such as Islam, Christianity, Buddhism, Hinduism, and Confucianism. As in the late 1990s, Indonesia was shocked by the bloody Ambon tragedy; religious issues were then used as a trigger for the occurrence of this tragedy ${ }^{2}$. Until May 2018, there were bombings in three churches in the city of Surabaya.

Based on the reporting from Tempo.co ${ }^{3}$, the Gusdurian Network noted that acts of intolerance and violence related to religion increased in 2018. Recently, the Church in Bantul was prohibited from holding social services with accusations of Christianization. On January

\footnotetext{
${ }^{1}$ https://www.bps.go.id/

2 https://international.sindonews.com/

${ }^{3}$ https://nasional.tempo.co/read/1053039/praperadilan-fredrich-yunadi-dipimpin-hakim-ratmoho-12-februari
} 
28, 2018, violence was experienced by the leader of the Al-Hidayah Cicalengka Islamic Boarding School, Bandung Regency, KH. Umar Basri. And on Thursday, February 1, the Persis PP Brigade Command was attacked by a man until he died. Of the many cases of intolerance among religious people in Indonesia, this certainly disturbs the comfort of the community to worship and incites hatred that can divide the unity of the Indonesian Nation.

This event certainly seemed to be a warning to the Indonesian people that the issue of harmony and religious tolerance was still a basic need. To make a country that is safe, peaceful, and upholds a high tolerance value, all elements of society, from the government, ulama, educators, security forces, and other community members need to work together to make it happen. However, before moving all elements of that society, we should start from each of us by tolerance.

Tolerance is not only the fundamental element in fostering a mutual understanding and respecting the cultural ${ }^{4}$ and religious diversity ${ }^{5}$, but it is also an entry point to realize the interreligious harmony and peace in this universe ${ }^{6}$. Accordingly, to avoid the interreligious conflicts, therefore, the tolerance should be a collective consciousness ${ }^{7}$ by all religious adherents in society ${ }^{8}$.

Fundamentally, every religion teaches peace and prosperity for its adherents. In reality, on the other hand, religion has often been a trigger for social conflict. It is due to the truth claim of religious adherents in interpreting the Holy Scripture teachings by a slogan that my religion is the only right religion ${ }^{9}$. However, every religion must have a truth system based on God as the single source of the truth ${ }^{10}$. Occasionally, the truth claims led to being a source of misinterpretation to the religious teaching caused by the subjective complaints and personal

\footnotetext{
${ }^{4}$ Taher, T. Aspiring for the Middle Path: Religious Harmony in Indonesia. Jakarta: CENSIS. 1997.

${ }^{5}$ Hisyam, M, Baroto E, Husein M.K. Budaya Kewargaan Komunitas Islam di Daerah Rentan Konflik. Jakarta: LIPI Press. 2006.

${ }^{6}$ Madjid, N. Indonesia Kita, Jakarta: PT Gramedia Pustaka Utama. 2004.

${ }^{7}$ Bahari, H. Toleransi Beragama Mahasiswa (Studi tentang Pengaruh Kepribadian, Keterlibatan Organisasi, Hasil Belajar Pendidikan Agama, dan Lingkungan Pendidikan terhadap Toleransi Mahasiswa Berbeda Agama pada 7 Perguruan Tinggi Umum Negeri). Ed 1 (1). Jakarta: Badan Litbang dan Diklat Kementerian Agama. 2010.

${ }^{8}$ Syarbini, A. Al-Qur'an dan Kerukunan Hidup Umat Beragama, Jakarta: PT Elex Media Komputindo. 2011.

${ }^{9}$ Amri, M., Afifuddin, A., \& Bin-Tahir, S. Z. Religious Pluralism of the Indonesian Traditional Islamic Education Institutions. The Journal of Social Sciences Research, 4(12), 2018. Pp.446-450.

10 Amri, M., Tahir, S. Z. A. B., \& Ahmad, S. 2017. The Implementation of Islamic Teaching in Multiculturalism Society: A Case Study at Pesantren Schools in Indonesia. Asian Social Science, 13(6), 125.
} 
judgment of the believers ${ }^{11}$. Consequently, various religious conflicts occurred in Indonesia, including the interreligious conflict that happened in Ambon, Maluku, in 1999 ${ }^{12}$.

Ambon is a city with a diverse population in terms of culture, ethnicity, language, and religion, and its community follows the different faiths, including Christianity, Islam, Catholicism, Hinduism, and Buddhism, and several local sects or beliefs. Based on the survey data in 2014, it shows that the Protestant population was $49.2 \%$, Muslims were $44.3 \%$, Catholics were $6.35 \%$, Hinduism was $0.07 \%$, and Buddhism was 0.04\%. This religious diversity is an asset of the cultural wealth that can benefit the government, as it is a source of inspiration for the process of the democratic consolidation, it could also potentially lead to a plurality of the social conflicts among religious followers as it happened in 1999 to $2011^{13}$.

One of the leading causes of religious conflict in Ambon was initially from the social and economic inequality problems. The immigrants from the Bugis, Butonese, and Makassar ethnics are known as hard-working and successful people who have a higher economic level than the natives of Ambon. This crucial situation has led to the accumulation of inequalities and hatred of the indigenous Ambones towards immigrant ethnicities. This ethnic issue subsequently spread out to the religious conflict between the Ambones Muslims and Christians that has killed 8-9 thousand people ${ }^{14}$.

The 1999 Ambon conflict became a conflict involving two religions, namely Islam and Christianity. The battle which is centered on religious identity is not only triggered by the basis of these beliefs. However, there are also other factors behind it. One of them is the social disparity that occurs in the region. So, this conflict is not solely aimed at the defense of religion. Many argue that the economic inequalities that occur are a result of the perception of both indigenous and immigrant Muslims. They have a good economy and have the opportunity to play a role in government.

The conflict tensions in 1999-2011 have left the wound and traumatic syndrome in the mindset of religious believers in the city of Ambon. It can be seen from their recent daily live activities, which tend to remain isolated and dwelled in certain areas based on their religious

\footnotetext{
${ }^{11}$ Bin-Tahir, S. Z., \& Rinantanti, Y. Multilingual lecturers' competence in english teaching at the university of Iqra Buru, Indonesia. Asian EFL Journal, 5, 2016, p.p. 79-92.

12 Bin-Tahir, S. Z., Bugis, R., \& Tasiana, R. Intercultural Communication of a Multicultural Family in Buru Regency. Lingual: Journal of Language and Culture, 9(2), 2017, p.8.

13 Amri, M., Tahir, S. Z. A. B., \& Ahmad, S. (2017). The Implementation of Islamic Teaching in Multiculturalism Society: A Case Study at Pesantren Schools in Indonesia. Asian Social Science, 13(6), 125.
} 
similarities. This situation is sensitive in triggering a new interreligious conflict among Ambones' community.

The process of fostering community peace due to the 1999 horizontal conflict took a long time and a long process because rebuilding mutual trust after the segregation that caused the trauma was not natural. Therefore, inculcation and strengthening of awareness of multicultural life and pluralism in society must continue. Its application requires a long process, character building, and awareness of religious life that must be continuously improved, especially at the base level, for example, in religious areas, the Koran teachers, priests who are in direct contact with the Moluccas.

Based on the background, the researchers intended to investigate the influence of knowledge, education level, perception, and attitude of Ambones Muslim society partially and collectively to the interreligious tolerance in Ambon City. They can be specified as follows: a) Is there a positive and significant influence of the Muslim community's knowledge towards the interreligious tolerance in Ambon; b) Is there a positive and considerable influence of educational level towards the interreligious tolerance in Ambon; c) Is there a positive and significant effect of the Muslim community's perception towards the interreligious tolerance in the city of Ambon; d) Is there a positive and significant influence of the Muslim community attitude towards the religious tolerance in Ambon; e) Are the knowledge, education level, perception, and attitude of the Muslim community collectively have a positive influence on the interreligious tolerance in the city of Ambon.

\section{B. Method}

This research applied a quantitative approach using survey design that employed a sample from a population using the questionnaire as the principal instrument of data collection ${ }^{15}$. The research sample was gained using a simple random sampling technique, which is drawn from $10 \%$ of the total of the population ${ }^{16}$. Thus, the number of samples in this study was 85 participants then be fulfilled to 100 samples.

The instrument of this study was the questionnaire, which is a technique to collect data by providing a set of statements or questions to respondents to be answered in writing or by checking the scale of the Likert Scale model that has been provided in the list of the questionnaire. The questionnaire can be closed or open questions and can be given to the

15 Singaribuan M. \& Effendi S. Metode Penelitian Survei, Lembaga Penelitian, Pendidikan dan Penerangan Ekonomi dan Sosial. Jakarta:LP3ES. 1989.

${ }^{16}$ Arikunto, S. Prosedur Penelitian Suatu Pendekatan Praktek, $8^{\text {th }}$ Edition. Jakarta: Rineka Cipta. 1998. 
respondent directly or by post ${ }^{17}$. The instrument used in this study has been qualified validity and reliability test as it was done by the empirical validity tested on 30 respondents who have similar characteristics to the population.

The collected data were analyzed as follows; 1) To examine the effect of independent variables $\mathrm{X} 1, \mathrm{X} 2, \mathrm{X} 3$, and $\mathrm{X} 4$ partially toward the dependent variable $\mathrm{Y}$ used the simple regression with the equation: $\widehat{Y}=a+b X ; 2)$ To examine the effect of independent variables $\mathrm{X} 1, \mathrm{X} 2, \mathrm{X} 3$, and $\mathrm{X} 4$ collectively to the dependent variable $\mathrm{Y}$ used inferential analysis with multiple regression equations.

\section{Concept of the Tolerance}

Religion is an exciting thing to be associated with because of its ability to move awareness of the unity of identity and vocation to become militants in upholding the struggle in the name of religion. Religion has never emerged as an initial motive in community conflict, but it cannot be denied that religion is often associated with different interests in society. Therefore religious groups need to be critical of this phenomenon and voice their deepest religious values or values about love, justice, peace and realize cooperation for the promotion of shared prosperity.

Religion should not be a reason for conflict or conflict, especially with violence, because basically, every religion teaches love. So that communication between religious believers should also be carried out in the awareness and character of love. Religious leaders must initiate this awareness.

One thing that needs to be considered to create harmony among religions amid this plurality is to understand the teachings of each faith in their entirety. Tensions and riots that have occurred in various regions in Indonesia so far have destroyed places of worship, such as mosques, mushallas, and churches, which are always associated with religious conflicts. The above phenomenon shows the gap between the ideals of religion (das sollen) as the teachings and holy messages of God with the empirical reality that occurs in society (das sein). Therefore, this problem must be immediately resolved, so that religious doctrines become increasingly meaningful for the creation of a harmonious life between religious believers. Recognizing religious pluralism that exists in Indonesia, harmony among religious believers is something that must be considered for the nature of national unity. Peace between

\footnotetext{
17 Sugiyono. S. Metode Penelitian Pendidikan Pendekatan Kuantitatif, Kualitatif, dan R\&D. Bandung: Alfabeta. 2010.
} 
religious communities is the tolerance created among religious people in social life without questioning the religion/creed of each religion.

The word 'tolerance' derived from the Latin language 'tolerare,' which means to endure or to bear something ${ }^{18}$. The term tolerance is defined as to carry on a shoulder, although the work was not favored ${ }^{19}$ or give a place to others even without an agreement ${ }^{20}$. Thus, tolerance refers to the existence of the willingness to accept the presence of different people. In Arabic, tolerance referred to tasamuh, which means allowing people to have a mutual understanding of one another and also to facilitate each other mutually ${ }^{21}$. The word tasamuh can be interpreted to those who disagree with other people, but they should be able to provide a place for other people's opinions ${ }^{22}$. Every person has the right to develop his ideas ${ }^{23}$ and does not hinder it from the others ${ }^{24}$.

With regard to this, Jalaluddin ${ }^{25}$ argued that tolerance is a term evolved in the disciplines of social, cultural, and religious sciences, which means the attitudes and acts that prohibit discrimination against the different groups or the actions which cannot be accepted by the majority of society.

The tolerance can be accomplished when there is a social awareness of diversity. According to Banawiratma ${ }^{26}$, two steps can be done to achieve tolerance. First, to appropriately act and behave toward other faiths that concretely support and create the tolerance between religious communities, and second, the society can influence the attitude and behavior that lead to the high tolerance among religious followers. Further, Banawiratna contended that the lack of citizen awareness of the diversity in society is due to the high vulnerability of conflict.

Conflict exists when people unable to think rationally and quietly, hence, they have been contaminated by a variety of interests, which tend to be emotional primordial. Then, they started to discriminate against people based on ethnicity, religion, race, and ethnic. These

${ }^{18}$ Gularnic, D.G. Webster's World Dictionary of American Language. New York: The World Publishing Company. 1959. p. 799.

${ }^{19}$ Reese, W.L. Dictionary of Philosophy and Religion: Eastern and Western Thought. Expanded Edition. New York: Humanity Books. 1999. p. 774-775.

${ }^{20}$ Siagian, S.H. Agama-agama di Indonesia. Semarang: Satya Wacana. 1993.

${ }^{21}$ Madjid, N. Pandangan Dunia Al-Qur'an: Ajaran Tentang Harapan Kepada Allah dan Seluruh Ciptaan," in Ahmad Syafii Maarif \& Said Tuhulelei, Al- Qur'an dan Tantangan Modernitas. Cet. II, Yogyakarta: SIPRESS. 1993.

${ }^{22}$ Badawi, A.Z. Mu jam Musthalahat al-'Ulum al-ljtima iiyat. Beirut: Maktabah Lubnan. 1982. p. 426.

${ }^{23}$ Munawir, A.W. Kamus al-Munawir. Yogyakarta: PP Krapyak. 1994. p. 702.

${ }^{24}$ El-Fadl, K.A. Cita dan Fakta Toleransi Islam: Puritanisme versus Pluralisme. Bandung: Arasy. 2003.

25 Jalaluddin, R. Psikologi Agama. Jakarta: Raja Grafindo Persada. 2008. p. 191.

${ }^{26}$ Banawiratma, J.B. Toleransi Beragama Mahasiswa. Jakarta: Badan Litbang dan Diklat Kementerian Agama. 2010. 
people eventually could not able to distinguish between right and wrong, and they became unable to understand the problem holistically. They have a narrow comprehension of religious teaching and have a bad experience with others that inclined to the negative prejudice on the particular ethnic or religious community ${ }^{27}$.

Tolerance and intolerance are indications of the mental characteristics of human behavior. It is the individual attitude dealing with several differences and even contradiction in views, beliefs, attitudes, and actions ${ }^{28}$. The individual personality and experience have influenced the emergence of tolerance and intolerance. Nature here can be defined as a combination of various properties and the self-concept that encompasses such aspects like character, knowledge, self-adjustment, interest, emotion, and attitude, as well as motivation ${ }^{29}$, while the experience is determined by the desire to engage in the social activities ${ }^{30}$. The desire to involve in community organization is really a fulfillment of the need to live in a society or live in a group ${ }^{31}$.

The cause of intolerance among religions does not derive from the religious teaching but entirely from the misunderstanding of spiritual teachings (kaffah), and how the religious adherents should behave and act to the other societies ${ }^{32}$. In principle, there is no religion in this world teaches the hostility, insult or denigrate other religions or faiths both in the Samawi religion (a religion that has a holy scripture and the prophet) and Ardhi religion (a religion that does not have a sacred Scripture and prophet $)^{33}$.

Shahab $^{34}$ asserted that religious tensions that occur so far are because the perpetrators of $d a^{\prime}$ wah (preachers, missionaries, missionaries) are people who love their religion, but do not have deep religious knowledge. As a result, his propaganda was more likely to be propagandist and sometimes provocative. This is where the need for openness between religious believers through fresh dialogues and soothing the people themselves. That is the

${ }^{27}$ Fatimah, E. Psikologi Perkembangan. Bandung: Pustaka Setia. 2006.

28 Bin-Tahir, S.Z. The Attitude of Santri and Ustadz toward Multilingual Education at Pesantren. International Journal of Language and Linguistics. Vol. 3, No. 4, 2015, pp. 210-216.

${ }^{29}$ Mujani, S. Benturan Peradaban: Sikap dan Perilaku Islamis Indonesia terhadap Amerika Serikat. Jakarta: Nalar. 2005. p. 92.

${ }^{30}$ Djaali, H. Psikologi Pendidikan. Jakarta: Bumi Aksara. 2008. p. 3.

${ }^{31}$ Sarwono, S.W. Psikologi Prasangka Orang Indonesia. Jakarta: Raja Grafindo Persada. 2006. p. 92.

32 Malik, G.F. Effords of Muslim Communities to Apply the Qur'anic Values towards World Peace: A Historical Perspective", International Conference Presentation, at Sahid Hotel of Makassar, 1-3 Juni 2001.

33 Madjid, N. Pandangan Dunia Al-Qur'an: Ajaran Tentang Harapan Kepada Allah dan Seluruh Ciptaan," in Ahmad Syafii Maarif \& Said Tuhulelei, Al- Qur'an dan Tantangan Modernitas. Cet. II, Yogyakarta: SIPRESS. 1993.

${ }^{34}$ Shahab-Ferdows, S., Engle-Stone, R., Hampel, D., Ndjebayi, A. O., Nankap, M., Brown, K. H., \& Allen, L. H. (2015). Regional, socioeconomic, and dietary risk factors for vitamin B-12 deficiency differ from those for folate deficiency in Cameroonian women and children. The Journal of nutrition, 145(11), 2587-2595. 
dialogue that is followed up with concrete work. How should the concept of interfaith dialogue be packaged? The praxis of authentic religious dialogue is the dialogue that immerses itself in reality and an unjust social order with a critical attitude because every religion has ethical values and a mission to uphold morality. It is not enough to build interfaith dialogue only with rational logic dialogues, but psychological logic is also necessary. So the logical discussions of harmony theology must also be accompanied by psychological dilutions, such as mutual suspicion that has always emerged among religious communities. Therefore, it is necessary to measure the social perception in building their knowledge, attitude, and awareness toward religious diversity.

\section{Perception and its Indicators}

Perception is the process of detecting a stimulus, and this meaning is constructed based on the physical representation that exists with the knowledge that we already have ${ }^{35}$. According to Slameto ${ }^{36}$, perception is a process that involves the entry of messages or information into the human brain. Through human perception, a continuous relationship with the environment will be sustainable. This relationship is done through the senses, namely the sense of sight, listener, touch, taste, and smell.

Meanwhile, according to Lombardo et $\mathrm{al}^{37}$, perception (perception) involves a high level of cognition in the interpretation of sensory information. Perception is divided into two forms, positive and negative; positive perception is an individual's assessment of an object or information with a positive view or following what is expected from the object perceived or from the existing rules. The cause of the emergence of positive perceptions is due to individual satisfaction with the purpose that is the source of their perception, the existence of personal knowledge, and the individual's experience of the object being perceived. Meanwhile, negative perceptions are individual perceptions of certain objects or information with negative views, contrary to what is expected from the perceived object or from existing rules. The cause of a person's negative perceptions can arise due to individual dissatisfaction

35 LATIPAH, S. PENGARUH PEMBELAJARAN MATEMATIKA MELALUI STRATEGI DISCOVERY-INQUIRY DAN LEARNING STATRS WITH A QUESTION (LSQ) TERHADAP PRESTASI BELAJAR SISWA DITINJAU DARI MOTIVASI BELAJAR SISWA (Pada Siswa Kelas VII Semester Ganjil MTs. Darun Ni'am Tahun Ajaran 2011/2012) (Doctoral dissertation, Universitas Muhammadiyah Surakarta).

36 Slameto, S. Pembelajaran Berbasis Riset Mewujudkan Pembelajaran Yang Inspiratif. Satya Widya, 31(2), 2015, 102-112.

37 Lombardo, M. V., Pierce, K., Eyler, L. T., Barnes, C. C., Ahrens-Barbeau, C., Solso, S., ... \& Courchesne, E. Different functional neural substrates for good and poor language outcome in autism. Neuron, 86(2), 2015. 567-577. 
with the object that is the source of his perception, the individual's ignorance, and the lack of individual experience of the object being perceived and vice versa.

The difference in perception can be traced to individual differences, differences in personality, differences in attitudes, or differences in motivation. For a believer, this means that he can obtain perceptions that are more or less the same as those of other religions. In other words, it can be said that no single method will be able to give the same results to groups or even different people or at different times.

According to Walgito in Saputra ${ }^{38}$, the perception has the following indicators:

a) Absorption

These stimuli or objects are absorbed or received by the five senses, both vision, hearing, touch, smell, and taste individually or together. From the results of absorption or reception by the sensory devices will get a picture, response, or impression in the brain. The view can be singular or plural, depending on the object of perception observed. In mind, collected images or ideas, both old and newly formed. Obviously, whether or not the picture depends on whether the excitement is evident, the normality of the senses and time, just or long ago.

b) Understanding or Understanding

After images or impressions occur in the brain, the images are organized, classified classified (assorted), compared, interpreted, so that formed understanding or understanding. The process of understanding is unique and fast. Understanding that is formed also depends on old images that have been owned by the individual before (called apperception).

c) Assessment or Evaluation

After an understanding is formed, an individual's judgment takes place. Individuals compare the new understanding or understanding that is obtained with the criteria or norms that are subjectively owned by individuals. Individual valuations vary even if the objects are the same. Therefore perception is individual.

Based on the opinions of the experts above, it can be concluded that perception is the process of entry of messages or information into the human brain through the senses, then constructed based on existing physical representation with the knowledge we already have. Based on this explanation also, this study tries to measure the perception of the Maluku

38 SAPUTRA, R. PENGARUH KEAKTIFAN MENGIKUTI LAYANAN KONSELING KELOMPOK TERHADAP KECERDASAN EMOSIONAL SISWA DI SEKOLAH MENENGAH PERTAMA NEGERI 4 SIAK HULU, 2018. (Doctoral dissertation, Universitas Islam Negeri Sultan Syarif Kasim Riau). 
Muslim community to find out how far the level of tolerance between religious communities in Maluku in dealing with conflicts that have or will occur.

\section{E. Results of Data Analysis}

The descriptive analysis results in determining the effect of knowledge, educational level, perception, and attitude toward the tolerance of Ambones Muslim community through distributing the questionnaire to 100 respondents can be described in table 1 below:

Table 1: Descriptive Analysis of Variables Knowledge, Education, Perception, and Attitude

\begin{tabular}{lcccccc}
\hline \multicolumn{1}{c}{ Variable } & N & Minimum & Maximum & Sum & Mean & $\begin{array}{c}\text { Std. } \\
\text { Deviation }\end{array}$ \\
\hline Knowledge & 100 & 45 & 90 & 5480 & 55 & 11.699 \\
Education & 100 & 21 & 46 & 2871 & 28.71 & 8.698 \\
Perception & 100 & 31 & 75 & 5364 & 53.64 & 11.352 \\
Attitude & 100 & 21 & 50 & 3202 & 32.02 & 8.075 \\
Tolerance & 100 & 16 & 46 & 2871 & 28.71 & 7.698 \\
\hline
\end{tabular}

Source: Research data, 2018

Table 1 illustrates the lowest score of the knowledge variable was 45, and the highest was 90, with the average value was 55. The standard deviation was 11.699 with the interpretation as much as $68 \%$, or the majority of the Muslim community has the knowledge level of tolerance ranged from 43.301 to 66.699 . The lowest score for the educational level was 21 , and the highest was 46 . The lowest score of perception was 31 , and the highest was 75 , it can be interpreted that $68 \%$ of Ambones' Muslim society has an impression of the tolerance ranged 42.288 to 64.992 . In contrast, the interpretation of the Muslim community attitude toward tolerance ranged from 23.574 to 39.946. As to determine the contribution of each research variable can be seen in Table 2 below:

Table 2: Analysis of Coefficient Correlation and Determination of Knowledge, Education, Perception, and Attitude toward the Tolerance

\begin{tabular}{lcccc}
\hline \multicolumn{1}{c}{ Model } & $\mathrm{R}$ & R Square & $\begin{array}{c}\text { Adjusted R } \\
\text { Square }\end{array}$ & $\begin{array}{c}\text { Std. Error of the } \\
\text { Estimate }\end{array}$ \\
\hline Knowledge & $.363^{\mathrm{a}}$ & .132 & .123 & .63736 \\
Education & $.442^{\mathrm{a}}$ & .196 & .187 & .61356 \\
Perception & $.370^{\mathrm{a}}$ & .137 & .128 & .63554 \\
Attitude & $.499^{\mathrm{a}}$ & .249 & .241 & .59297 \\
Collectively & $.653^{\mathrm{a}}$ & .427 & .403 & .52604 \\
\hline
\end{tabular}


Source: Research data, 2018

Table 2 shows that the knowledge variable has a weak relationship to the tolerance whereby the coefficient of correlation was 0.363 , and the coefficient of determination was equal to 0.132 . This means that the level contribution of knowledge towards the tolerance was $13.2 \%$ and the rest of the contributions derived from other variables. While the education level has strong enough relationship to the tolerance in which the coefficient of correlation was 0.442 , and the coefficient of determination was 0.196. It means that the level of education contributed $19.6 \%$ towards tolerance.

The perception variable has a strong enough relationship to the tolerance whereby the coefficient of correlation was 0.370 , and the coefficient of determination was 0.137 . This means that the level contribution of the perception towards tolerance was $13.7 \%$. While the attitude has a strong enough relationship to the tolerance in which the coefficient of correlation was 0.499 , and the coefficient of determination was 0.249 . That means that the contribution of the attitude towards tolerance was $24.9 \%$ and the rest of the contributions derived from other variables.

The results of the analysis also found that the coefficient of correlation (RR) was 0.653. It showed a strong correlation to the value of the determination coefficient (R2) was 0.427 . This means that the contribution level of knowledge, education level, perception, and attitude impact collectively toward the interreligious tolerance was $42.7 \%$, and the rest contributions $(57.3 \%)$ originated from other variables that were not addressed in this study.

To determine the influence of knowledge, education level, perception, and attitude towards the tolerance of Ambones' Muslim community in this study using a probability value were 0.005. The analysis results can be presented in Table 2 as follows:

Table 3: Regression Analysis of Knowledge, Education level, Perception, and Attitude toward the Tolerance

\begin{tabular}{llccccc}
\hline \multirow{2}{*}{ Model } & \multicolumn{2}{c}{$\begin{array}{c}\text { Unstandardized } \\
\text { Coefficients }\end{array}$} & $\begin{array}{c}\text { Standardized } \\
\text { Coefficients }\end{array}$ & \multirow{2}{*}{$\mathrm{T}$} & Sig. \\
\cline { 2 - 4 } & \multicolumn{1}{c}{$\mathrm{B}$} & Std. Error & Beta & & \\
\hline 1 & (Constant) & .619 & .322 & & 1.923 & .057 \\
& Attitude & .415 & .086 & .397 & 4.853 & .000 \\
& Perception & .138 & .104 & .115 & 1.323 & .189 \\
Education & .201 & .076 & .230 & 2.640 & .010 \\
& Knowledge & .205 & .073 & .233 & 2.787 & .006 \\
\hline
\end{tabular}


Source: Research data, 2018

Table 3 shows the regression of each variable partially, namely knowledge, education level, perception, and attitude of the Muslim community in Ambon has a relationship with the interreligious tolerance, but the data obtained indicated that the contribution of the perception of Ambones' Muslim community was considerably low. In contrast, the education level has a high contribution to interreligious tolerance. However, the combined regression for all variables collectively has a significant relationship and effect of increasing interreligious tolerance. The regression table also shows that to increase the interreligious tolerance of the Ambones' Muslim community should be integrated collectively and not partially.

\section{F. Discussion}

The significant influence of the Muslim community's knowledge toward the interreligious tolerant in Ambon contributed as much as 13.2\%. It means that the knowledge of Muslim society has not been able to encourage them to be involved in interreligious tolerance activities. On the other word, the knowledgeable people without having the interreligious awareness will make them apathetic towards tolerance.

The insufficient of Muslim society's knowledge has an impact on the less participation of the society in the interreligious tolerance activities. This is caused by the notion that defined knowledge as the basis to behave properly and can be socialized in the real circumstances and in real conditions, as well as the ability to justify, assess, and evaluate the interreligious tolerance activities based on the principles of sustainability ${ }^{39}$.

The influence of the education level of Muslim society toward the interreligious tolerance in Ambon contributed 18.6\%. It indicated that the level of education has not been able to encourage the Muslim community to engage voluntarily in the tolerance activities among the religious community. This is due to the low Muslim educational level, so it is difficult to mobilize the community to tolerate actively in the socio-religious programs. The characteristics of the Muslim community in Ambon were more concerned with the interest of individuals in the form of learning, teaching, and acquiring Islamic knowledge compared to engage in the tolerance activity.

The tolerance or mutual respect for differences is important in the life of the nation and religion. However, not everyone can implement this. The attitude of tolerance towards a difference can be determined through the level of knowledge possessed by someone. The

${ }^{39}$ Malik, G.F. Effords of Muslim Communities to Apply the Qur'anic Values towards World Peace: A Historical Perspective", International Conference Presentation, at Sahid Hotel of Makassar, 1-3 Juni 2001. 
higher or more extensive a person's knowledge, the higher the tolerance level, and vice versa. If someone's knowledge is narrow, then the level of tolerance is also narrow or low.

The influence of the Muslim community's perception towards religious tolerance in Ambon had a contribution of $13.7 \%$. This shows that the community's perception cannot change the level of interreligious tolerance of the Ambones Muslim community. This is due to their knowledge and experience to the previous conflict occurred and the characteristics which tend to be negative prejudices to other religious followers as the factors that increasingly influenced the interreligious tolerance in $\mathrm{Ambon}^{40}$.

The community's experience in the conflict occurred in 1999 has led to a traumatic syndrome and negative prejudice against all form of activities on behalf of the tolerance. This experience and perception which provoked a negative expectation towards the entire socioreligious program organized by the government or the private agencies. As noted by Arends ${ }^{41}$ that the negative expectations of the community will significantly influence their perceptions and attitude toward the socio-religious program ${ }^{42}$.

The process of fostering community peace due to the 1999 horizontal conflict took a long time and a long process because rebuilding mutual trust after the segregation that caused the trauma was not easy. Therefore, inculcation and strengthening of awareness of multicultural life and pluralism in society must continue. Its application requires a long process, character building, and awareness of religious life that must be continuously improved, especially at the base level, for example, in religious areas, the Koran teachers, priests who are in direct contact with the Moluccas.

The Muslim society's attitude towards interreligious tolerance in Ambon has contributed by $24.9 \%$. It shows that the community's attitude has not contributed significantly to increasing the tolerance among religions in Ambon city. It is due to the Muslims' attitude, which evolving directly to the community awareness behaving. As many experts stated that the attitude associated with the behavior in the real context which contains three components, namely the attitude of cognitive, affective, and psychomotor. The individual attitude is usually consistent between those components in cognitive and actions.

The effect of knowledge, education level, perception, and attitude of the Ambones Muslim community toward interreligious tolerance has contributed quite high at $42.7 \%$. It

40 Banawiratma, J.B. Toleransi Beragama Mahasiswa. Jakarta: Badan Litbang dan Diklat Kementerian Agama. 2010.

${ }^{41}$ Arends, I.R. Teaching To Teach, seventh edition. New York. Mc Graw Hill Companies, Inc 1221 Avenue of the Americas. 2007.

${ }^{42}$ Sarwono, S.W. Psikologi Prasangka Orang Indonesia. Jakarta: Raja Grafindo Persada. 2006. p. 92. 
means that the entire variables collectively influence the interfaith tolerance of the Muslim community in Ambon. But partially, the community's perception does not have significant effect toward the interreligious tolerance because of the three variables (knowledge, education level, and attitude) are the underlying factor that related to the basis of human need directly in which the knowledge has a role in planning, utilization, and evaluation of the socio-religious relationship. In contrast, the low level of education will affect the tendency to be intolerant.

Based on the results of an analysis of the level of education knowledge, attitudes towards tolerance of the Moluccans, we found several factors that directly influence intolerant behavior: religious fanaticism, distrust of other religions and ethnicities, feelings of suspicion about other religions, secularism, feelings of being threatened, and information on social media.

Respondents who felt threatened and suspected followers of other religions and people of different ethnicities tended to become intolerant. The same tendency is also found in those who have a high level of religious fanaticism and those who use social media actively. The results of this study also showed that suspicion of different parties' beliefs contributed to the growth of intolerant attitudes. Our respondents say that people with different beliefs or religions cannot be trusted and tend to exploit others when they are in power. This data also shows that respondents felt threatened when followers of different religions became important officials and had power in the economic and political sectors. Besides, this study also found that the more secular a person is, the higher the tolerance level of that person. In this case, the identification of a person's secular level is not only measured based on the values of beliefs or religions held but also based on their views on the role of the state (government) to protect the rights of every citizen of a different religion.

In preventing religious conflicts, there are a number of suggestions that need attention, namely, increase religious knowledge and re-understand the teachings of religion correctly that God did create different religions because diversity is intended to test us all so that we compete in the pursuit of goodness. Because in the end, all religions believe, all people will return to God, whether Islam, Protestant Christianity, Catholicism, Hinduism, Buddhism, Confucianism, and various other religions in the world. And our task here is to resolve differences between various religions with an attitude of tolerance. We cannot take religious differences in any way, including the fatwa. Remember that being religious does not necessarily make us God. 
It is necessary to foster a sense of nationalism within. As part of Indonesian citizens, it's good that we not only know and memorize the contents of the Pancasila, but also understand the meaning of each principle. As in the first principle of Pancasila, the religious aspect is mentioned first. This is a sign that religion is one of human freedom to believe what it believes. Besides, we, as Indonesian citizens, must hold fast to the values of Pancasila in every activity we do. Remembering that Pancasila is the basis and ideology of the state. In addition to understanding Pancasila, remembering the Indonesian motto, which reads "Unity in Diversity," was also felt to be very necessary. This motto means that with all the differences but still one.

In addition, we must maintain mutual friendship between religious communities so as not to be suspicious of each other. Communicating with one another with other religious communities. Discussion is also important. So that we know what the teachings of other religions are like. From there, our insights and thoughts are wide open. That way, mutual suspicion, judging the behavior of other people or groups, and an attitude of intolerance do not occur.

\section{G. Conclusion}

Based on the results and discussion above, the researchers conclude the following:

a. There was a positive and significant influence of the Muslim community's knowledge towards the interreligious tolerance in Ambon, whereby the lack of knowledge will impact on the low of interreligious tolerance.

b. There was a positive and significant influence of educational level towards the interreligious tolerance in Ambon in which the low level of education will affect the low level of tolerance.

c. There was a positive and significant effect of the Muslim community's perception towards the interreligious tolerance in the city of Ambon.

d. There was a positive and significant influence of the Muslim community attitude towards the religious tolerance in Ambon.

e. The knowledge, education level, perception, and attitude of the Muslim community collectively have a positive influence on the interreligious tolerance in the city of Ambon. But the perception was not significantly affecting the tolerance. This variable collectively will provide a significant contribution to encouraging the increase of awareness and the attitude of the Muslim community to uphold the interreligious understanding. 
The researchers suggest the involvement of the government and religious leaders' role to enhance the community's comprehension of religious teachings and awareness of diversity through religious dialogue programs, increasing the educational level of the community, socialization the importance of the interreligious tolerance, forming the socio-religious groups in empowering the diversity as a socio-cultural wealth in the city of Ambon, increasing the community's intercultural competence, organizing social activities to fostering a sense of nationalism, and liberating the government affairs from religious affairs. The results of this study are expected to provide technical and practical information and references for the governments, the further researchers, and other interested parties to prevent, minimize, manage, and offer solutions to the new unpredictable conflicts that have the potential to recur in Ambon in particular and generally in Maluku.

\section{BIBLIOGRAPHY}

Abu-Bakar, A. 2006. Islam yang Paling Toleran: Kajian tentang Fanatisme dan Toleransi dalam Islam. Jakarta: Pustaka Al-Kautsar.

Abdul Haris, F. (2020). KONFLIK POLITIK ANTARA ANGKATAN DARAT DPRS DAN SUKARNO: STUDI KASUS PERISTIWA 17 OKTOBER 1952: Political Conflict between the DPRS Army and Sukarno: Case Study of the October 17, 1952. Uniqbu Journal of Social Sciences, 1(1), 38-44. Retrieved from http://ejournaluniqbu.ac.id/index.php/ujss/article/view/8

Amri, M., Tahir, S. Z. A. B., \& Ahmad, S. 2017. The Implementation of Islamic Teaching in Multiculturalism Society: A Case Study at Pesantren Schools in Indonesia. Asian Social Science, 13(6), 125.

Amri, M., Afifuddin, A., \& Bin-Tahir, S. Z. 2018. Religious Pluralism of the Indonesian Traditional Islamic Education Institutions. The Journal of Social Sciences Research, 4(12), 446-450.

Bahari, H. 2010. Toleransi Beragama Mahasiswa (Studi tentang Pengaruh Kepribadian, Keterlibatan Organisasi, Hasil Belajar Pendidikan Agama, dan Lingkungan Pendidikan terhadap Toleransi Mahasiswa Berbeda Agama pada 7 Perguruan Tinggi Umum Negeri). Ed 1 (1). Jakarta: Badan Litbang dan Diklat Kementerian Agama.

Bin-Tahir, S. Z., \& Rinantanti, Y. 2016. Multilingual lecturers' competence in english teaching at the university of Iqra Buru, Indonesia. Asian EFL Journal, 5, 79-92.

Bin-Tahir, S. Z., Bugis, R., \& Tasiana, R. 2017. Intercultural Communication of a Multicultural Family in Buru Regency. Lingual: Journal of Language and Culture, 9(2), 8 .

Bin-Tahir, S.Z. 2015. The Attitude of Santri and Ustadz toward Multilingual Education at Pesantren. International Journal of Language and Linguistics. Vol. 3, No. 4, 2015, pp. 210-216. doi: 10.11648/j.ijl1.20150304.13.

Bin Tahir, S. Z. (2013). Pengajaran Bahasa Inggris-Teaching English as World Language. Jakarta: Media Pustaka Qalam. 
Bin-Tahir, S. Z., Atmowardoyo, H., Dollah, S., \& Rinantanti, Y. (2017). Multilingual Instructional Model of Pesantren Schools in Indonesia. Journal of Language Teaching and Research, 8(6), 1210-1216.

Elpisah. (2020). PENERAPAN MODEL PEMBELAJARAN KOOPERATIF TIPE STUDENT TEAMS ACHIEVEMENT DIVISION (STAD) UNTUK MENINGKATKAN HASIL BELAJAR SISWA: STUDENT TEAMS ACHIEVEMENT DIVISION (STAD) TYPE COOPERATIVE LEARNING MODEL TO IMPROVE STUDENT LEARNING OUTCOMES. Uniqbu Journal of Social Sciences, 1(1), 45-52. $\quad$ Retrieved from http://ejournaluniqbu.ac.id/index.php/ujss/article/view/9

El-Fadl, K.A. 2003. Cita dan Fakta Toleransi Islam: Puritanisme versus Pluralisme. Bandung: Arasy.

Gularnic, D.G. 1959. Webster's World Dictionary of American Language. New York: The World Publishing Company. 1959. p. 799.

Hisyam, M, Baroto E, Husein M.K. 2006. Budaya Kewargaan Komunitas Islam di Daerah Rentan Konflik. Jakarta: LIPI Press.

Karim, Asman Budiman, Muhammad Yusnan \& Taufik. (2020). ASPEK SPIRITUAL DALAM NOVEL TUHAN IZINKAN AKU MENJADI PELACUR KARYA MUHIDIN M DAHLAN : Spiritual Aspects In The Lovely Of God Let Me Become A Property Of Muhidin M Dahlan. Uniqbu Journal of Social Sciences, 1(1), 61-71. Retrieved from http://ejournal-uniqbu.ac.id/index.php/ujss/article/view/11

Kurroti A'yun \& Suyono. (2020). HUBUNGAN TINGKAT KONFLIK KOGNITIF TERHADAP BEBAN MISKONSEPSI MAHASISWA CALON GURU KIMIA: The Relationship of Cognitive Conflict of Misconception Load of Prospective Chemistry Teacher's-Student). Uniqbu Journal of Exact Sciences, 1(1), 1-8. Retrieved from http://ejournal-uniqbu.ac.id/index.php/ujes/article/view/6

Lombardo, M. V., Pierce, K., Eyler, L. T., Barnes, C. C., Ahrens-Barbeau, C., Solso, S., ... \& Courchesne, E. 2015. Different functional neural substrates for good and poor language outcome in autism. Neuron, 86(2), 567-577.

Madjid, N. 1993. Pandangan Dunia Al-Qur'an: Ajaran Tentang Harapan Kepada Allah dan Seluruh Ciptaan," in Ahmad Syafii Maarif \& Said Tuhulelei, Al- Qur'an dan Tantangan Modernitas. Cet. II, Yogyakarta: SIPRESS.

Malik, G.F. 2001. Effords of Muslim Communities to Apply the Qur'anic Values towards World Peace: A Historical Perspective", International Conference Presentation, at Sahid Hotel of Makassar, 1-3 Juni 2001.

Muhammad Yusnan, Kamasiah, Risman Iye, Karim, Harziko, Riki Bugis. (2020). ALIH KODE DAN CAMPUR KODE PADA NOVEL BADAI MATAHARI ANDALUSIA KARYA HARY EL-PARSIA: Transfer code and mix code in Novels Badai Matahari Andalusia Karya Hary El-Parsia. Uniqbu Journal of Social Sciences, 1(1), 1-12. Retrieved from http://ejournal-uniqbu.ac.id/index.php/ujss/article/view/3

Nuril Mufidah \& Intan Izha Rohima. (2020). PENGAJARAN KOSA KATA UNTUK MAHASISWA KELAS INTENSIF BAHASA ARAB: Vocabulary Teaching For Arabic Intensive Class. Uniqbu Journal of Social Sciences, 1(1), 13-24. Retrieved from http://ejournal-uniqbu.ac.id/index.php/ujss/article/view/7 
SAPUTRA, R. 2018. PENGARUH KEAKTIFAN MENGIKUTI LAYANAN KONSELING KELOMPOK TERHADAP KECERDASAN EMOSIONAL SISWA DI SEKOLAH MENENGAH PERTAMA NEGERI 4 SIAK HULU (Doctoral dissertation, Universitas Islam Negeri Sultan Syarif Kasim Riau).

Reese, W.L. 1999. Dictionary of Philosophy and Religion: Eastern and Western Thought. Expanded Edition. New York: Humanity Books. 1999. p. 774-775.

Risman Iye, A. Yusdianti Tenriawali, Susiati, Azwan, and Darwis Buton. (2020). MAKNA DAN FUNGSI EMOSI MAHASISWA KOTA BAUBAU DALAM RANAH DEMONSTRASI: THE MEANING AND EMOTIONAL FUNCTION OF STUDENTS OF BAUBAU CITY IN THE DEMONSTRATION PLAN. Uniqbu Journal of Social Sciences, 1(1), 25-37. Retrieved from http://ejournaluniqbu.ac.id/index.php/ujss/article/view/4

Saidna Zulfiqar Bin-Tahir, Hanapi Hanapi, Ibnu Hajar, Aminah Suriaman. (2020). AVOIDING MALUKU LOCAL LANGUAGES DEATH THROUGH EMBEDDED MULTILINGUAL LEARNING MODEL: Menghindari Kematian Bahasa Daerah Maluku melalui Model Pembelajaran Embedded Multilingual. Uniqbu Journal of Social Sciences, 1(1), 53-60. Retrieved from http://ejournaluniqbu.ac.id/index.php/ujss/article/view/10

Taher, T. 1997. Aspiring for the Middle Path: Religious Harmony in Indonesia. Jakarta: CENSIS.

Tahir, S. Z. B. (2015). Multilingual Teaching And Learning At Pesantren. 14 Asian EFL Journal Conference.

Wa Malmia, Sitti Hajiyanti Makatita, Jalil Muna. (2020). PENGARUH MINAT DAN KREATIVITAS BELAJAR TERHADAP PRESTASI BELAJAR MATEMATIKA SISWA KELAS VII SMP NEGERI 3 BURU: The Influence of Interest and Creatifity Learning on Mathematics Achievement of Students at SMP Negeri 3 Buru. Uniqbu Journal of Exact Sciences, 1(1), 9-14. Retrieved from http://ejournaluniqbu.ac.id/index.php/ujes/article/view/5 